\title{
Review \\ Sleeve Gastrectomy and Roux-En-Y Gastric Bypass. Two Sculptors of the Pancreatic Islet
}

\author{
Gonzalo-Martín Pérez-Arana 1,2,3,* , José Fernández-Vivero ${ }^{1}$, Alonso Camacho-Ramírez ${ }^{1,3,4}$ (D), \\ Alfredo Díaz Gómez ${ }^{5}$, José Bancalero de los Reyes ${ }^{6}$, Antonio Ribelles-García 1, David Almorza-Gomar 2,7, \\ Carmen Carrasco-Molinillo ${ }^{1}$ and José-Arturo Prada-Oliveira ${ }^{1,2,3, *}$
}

check for updates

Citation: Pérez-Arana, G.-M.;

Fernández-Vivero, J.;

Camacho-Ramírez, A.; Díaz Gómez,

A.; Bancalero de los Reyes, J.;

Ribelles-García, A.; Almorza-Gomar,

D.; Carrasco-Molinillo, C.;

Prada-Oliveira, J.-A. Sleeve

Gastrectomy and Roux-En-Y Gastric

Bypass. Two Sculptors of the

Pancreatic Islet. J. Clin. Med. 2021, 10,

4217. https://doi.org/10.3390/

jcm10184217

Academic Editor: David Benaiges

Boix

Received: 22 July 2021

Accepted: 14 September 2021

Published: 17 September 2021

Publisher's Note: MDPI stays neutral with regard to jurisdictional claims in published maps and institutional affiliations.

Copyright: (c) 2021 by the authors. Licensee MDPI, Basel, Switzerland. This article is an open access article distributed under the terms and conditions of the Creative Commons Attribution (CC BY) license (https:// creativecommons.org/licenses/by/ $4.0 /)$.
1 Department of Human Anatomy and Embryology, Faculty of Medicine, University of Cadiz, 11003 Cadiz, Spain; jose.vivero@uca.es (J.F.-V.); alonso.camacho@uca.es (A.C.-R.); Antonio.ribelles@uca.es (A.R.-G.); carmen.carrasco@uca.es (C.C.-M.)

2 Institute for Biomedical Science Research and Innovation (INIBICA), University of Cadiz, 11003 Cadiz, Spain; david.almorza@uca.es

3 Asociación Gaditana de Apoyo al Investigador (AGAI), 11012 Cadiz, Spain

Surgery Unit, Puerta del Mar Universitary Hospital, University of Cadiz, 11003 Cadiz, Spain

5 San Carlos Hospital, Andalusian Health System, 28040 Madrid, Spain; diazgomez.a@gmail.com

6 Badajoz Hospital, Extremadura Health System, 06001 Badajoz, Spain; josebancalerodelosreyes@gmail.com

7 Operative Statistic and Research Department, University of Cadiz, 11003 Cadiz, Spain

* Correspondence: gonzalo.perez@uca.es (G.-M.P.-A.); arturo.prada@uca.es (J.-A.P.-O.)

\begin{abstract}
Several surgical procedures are performed for the treatment of obesity. A main outcome of these procedures is the improvement of type 2 diabetes mellitus. Trying to explain this, gastrointestinal hormone levels and their effect on organs involved in carbohydrate metabolism, such as liver, gut, muscle or fat, have been studied intensively after bariatric surgery. These effects on endocrine-cell populations in the pancreas have been less well studied. We gathered the existing data on these pancreatic-cell populations after the two most common types of bariatric surgery, the sleeve gastrectomy (SG) and the roux-en-Y gastric bypass (RYGB), with the aim to explain the pathophysiological mechanisms underlying these surgeries and to improve their outcome.
\end{abstract}

Keywords: sleeve gastrectomy; roux-en-Y gastric bypass; beta-cell; alpha-cell; epsilon-cell; islet; trans-differentiation

\section{Introduction}

Bariatric/metabolic surgery has been a powerful tool for the treatment of diabetes mellitus for a long time. Sleeve gastrectomy (SG) and roux-en-Y gastric bypass (RYGB) are two of the most performed ones [1,2] as Figure 1 shows.

Changes in energy homeostasis and body fat mass have been proposed as a primary mechanism to explain these phenomena $[3,4]$, but other mechanisms such as changes in several gastrointestinal hormones also seem to be involved with a large number of publications written on the topic. Many of them have related the anatomical changes in the gastrointestinal tract after surgery with the modification of serum levels of glucagon like peptide-1 (GLP-1) [5], ghrelin [6], peptide tyrosine-tyrosine (PYY) [7], gastrointestinal inhibitory peptide (GIP) [8], or even leptin [9], among others, in humans and animal models. Their involvement is clear, but the exact mechanisms and their degree of participation remain partially unknown.

At the other end of the entero-pancreatic axis, the endocrine pancreas containing Langerhans islets determines changes in carbohydrate metabolism after bariatric/metabolic surgery. Their hormonal secretions before and after bariatric/metabolic surgery have been widely studied in plasma or serum from animals and humans $[10,11]$ but the islet cell composition and its paracrine interactions have been studied less. We will attempt to 
summarize what we know about the subject by means of a bibliographical review of the most relevant works published on the subject.

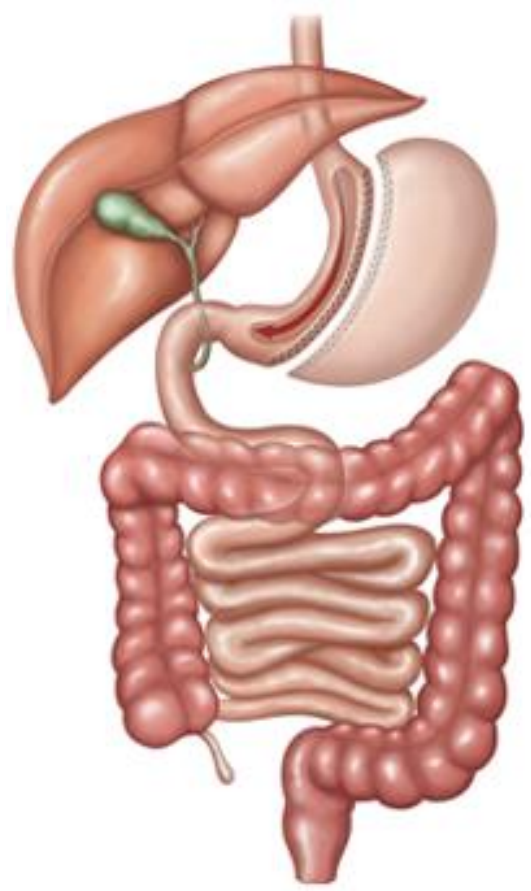

(A)

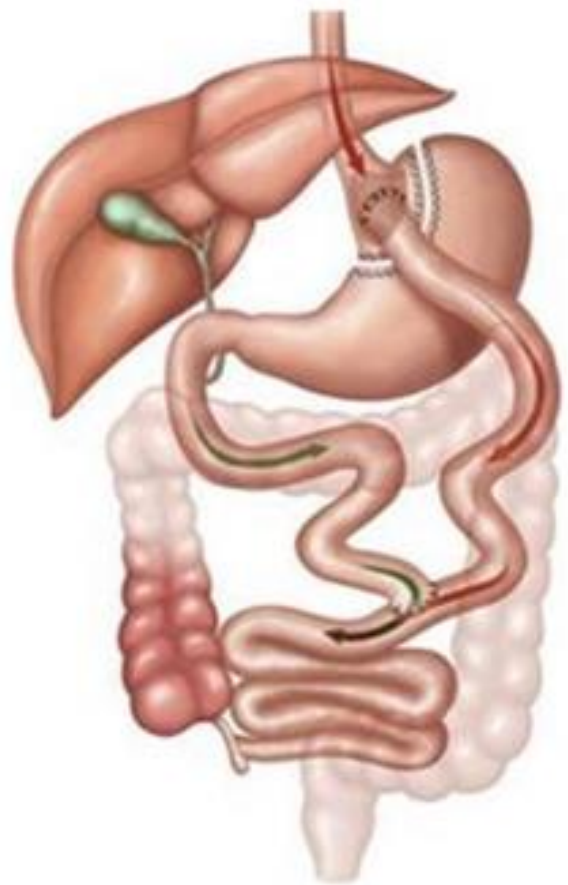

(B)

Figure 1. Schematic drawing of Sleeve Gastrectomy and Roux-en-Y Gastric bypass. (A) Sleeve Gastrectomy (SG). Representation of a common human sleeve gastrectomy (SG) procedure. The SG is a surgical procedure including a reduction of final gastric volume, since most of the gastric major curvature is resected. The stomach is reduced to a cylindrical pouch removing most of the fundus, stomach-corpus and antrum. The pylorus and minor curvature is preserved. SG reduces the initial stomach volume by approximately $15-20 \%$. In animal models this configuration is maintained since the final gastric pouch volume and valves are preserved. (B) Roux-en-Y Gastric Bypass (RYGB). Representation of a common human roux-en-Y gastric bypass (RYGB) surgery. This includes a transverse section of the stomach performed from the major to the minor curvature, configuring a gastric pouch. This pouch of the stomach continues to the food handle with an alimentary bulb, which continues with the medium portion of the jejunum. RYGB, a mixed malabsorptive and restrictive technique, excludes the antrum and the proximal intestine to aliments by bypassing the duodenum and the initial part of the jejunum. This includes biliopancreatic secretion, which determines the malabsorptive component. The biliopancreatic bulb connects with the mid jejunum. In rats, the model was reproduced similarly with minor modifications according to the animal anatomy. Exempli gratia, the jejunal alimentary bulb was $10 \mathrm{~cm}$ due to the usual intestinal medium extension of $80 \mathrm{~cm}$. Original figure seen in https://sagebariatric.com/about-surgery-home/sleeve-gastrectomy (accessed on 22 July 2021).

\section{Methods and Results}

This paper is a narrative literature review text that aims to expose the framework surrounding the effects of RYGB and SG on endocrine-cell populations in the pancreas. We performed a selective search of numerous articles in different databases, as well as books.

The literature of the main scientific databases was reviewed. The search was limited to documents published between 2001 and 2021. These databases were Medline, PubMed, Chochrane and Scopus. In addition, a search was carried out on academic websites, such as Google Scholar, SciELO and Dialnet. The main Boolean operators used were: AND, OR and NOT, and the key words were sleeve gastrectomy; roux-en-Y gastric bypass; beta-cell, alpha-cell; epsilon-cell; islet; trans-differentiation. Due to the large number of studies found, the following criteria were applied to filter the results and work with the most relevant studies.

Inclusion criteria: Original articles, systematic reviews and meta-analyses concerning modifications of the endocrine pancreas after bariatric or metabolic surgery in humans or 
animal models. Papers published in English in the last 20 years (2001-2021). We prioritised information from systematic reviews and meta-analyses with high scientific evidence.

Exclusion criteria: Papers not related to the topic or not meeting the inclusion criteria. In the end, a total of 435 articles were found that met the search criteria. Of these, 47 were selected for the preparation of this manuscript. As Table 1 shows, a large number of disciplines are involved in the study of the topic.

Table 1. Search Results. Break down of the total number of articles used to prepare the work. The left column represents the different fields of research of each journal citation (Journal Citation Report categories). The central column contains the number of citations found in each category and the right column contains the number and percentage of citations selected for the manuscript.

\begin{tabular}{ccc}
\hline Research Field (JCR) & Number of Articles Obtained & $\begin{array}{c}\text { Number and \% of Articles } \\
\text { Selected }\end{array}$ \\
\hline Endocrinology \& Metabolism & 223 & $22(46.80 \%)$ \\
Surgery & 91 & $6(12.76 \%)$ \\
Cell Biology & 29 & $4(8.50 \%)$ \\
Medicine General \& Internal & 27 & $4(8.50 \%)$ \\
Biochemistry \& Molecular Biology & 21 & $2(4.25 \%)$ \\
Multidisciplinary Sciences & 14 & $2(4.25 \%)$ \\
Medical Research \& Experimental & 11 & $2(4.25 \%)$ \\
Gastroenterology \& Hepatology & 11 & $2(4.25 \%)$ \\
Genetics \& Heredity & 4 & $1(2.12 \%)$ \\
Pediatrics & 3 & $1(2.12 \%)$ \\
Peripheral Vascular disease & 1 & $1(2.12 \%)$ \\
Total of Research fields & 435 & $47(100 \%)$ \\
\hline
\end{tabular}

\section{Discussion}

\subsection{The Sleeve Gastrectomy and the Islet Architecture}

Bariatric/metabolic surgery involves different techniques leading to different effects on pancreatic cell populations. Currently, sleeve gastrectomy (SG) is one of the most performed techniques. A consequence of this procedure is the drastic removal of the gastric fundus and corpus ghrelin-producing cell population. This situation leads to $35-45 \%$ reduction of blood ghrelin levels after gastrectomy in humans [12-14]. However, a recent study described the expansion of the pancreatic residual postnatal epsilon-cell population with recovery of plasma ghrelin levels in rats twelve weeks after SG. This expansion takes place at the expense of pancreatic cell progenitors that differentiate into epsilon-cells showing a high expression of lineage markers such as neurogenin-3 (Ngn-3) but not homeodomain protein Nkx2.2 (Figure 2) [15].

This leads us to believe in an adaptive response of the endocrine pancreas to low circulating ghrelin levels and in a possible explanation of the improvement of beta cell function after SG if we take into account the protective role of ghrelin on it [16].

Furthermore, this surgery does not only affect the epsilon-cells in the islets. It is clear that SG preserves the beta-cell function, at least for a while [17,18]. This could be explained by the increase of GLP-1 receptor expression in beta cells after SG, implying an increase in paracrine sensitivity to GLP-1 $[19,20]$. However, there are doubts about this due to a recent study with a modified mouse model involving an inducible knockdown of GLP-1r in beta-cells (GLP1r $\beta$-cell-ko), which showed improved glycemic profiles, to the wild-nature level, after SG [21]. Other researchers have linked the maintenance of beta-cell mass and beta-cell identity markers such as PDX-1 or MafA [22] (Picture 2) to high levels of gastrin after SG, as well as to correction of long-term blood glucose levels in rodents [23]. 


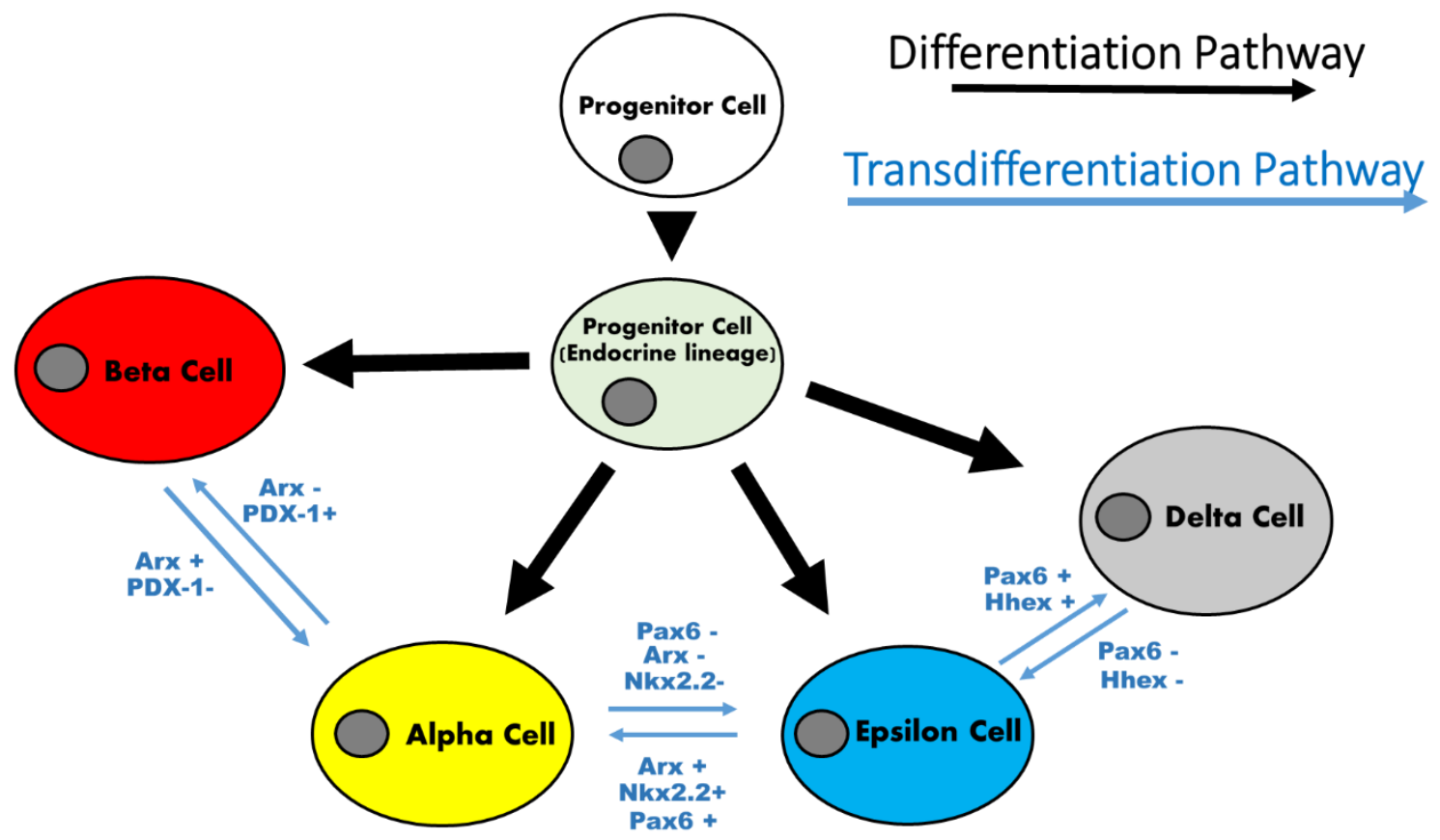

Figure 2. Pancreatic endocrine cell identity markers and possible cell trans/differentiation pathways after SG/RYGB. Pancreatic endocrine-cell identity markers and possible cell differentiation pathways from progenitor-cells (Black arrows) or trans-differentiation from other pancreatic endocrine-cells (Blue arrows) after sleeve gastrectomy or roux-en-Y gastric bypass.

This brings us to the problem of diabetes relapse after SG, which is as high as $41.6 \%$ of cases five years after surgery [2]. Liu et al. proposed long-term recovery of insulin sensitivity without beta-cell dysfunction as an answer to the question [24], but a recent work showed loss of beta-cell mass and a strong increase in alpha-cell mass in Wistar rats twelve weeks after SG. Trans-differentiation of the beta-cell population under stressful situations with loss of beta-cell markers such as PDX-1 and gain of alpha-cell markers such as Pax-6 and Arx has been shown [25] (Figure 2). Moreover, this is supported by studies performed on mice outside the scope of bariatric surgery where alpha-cell populations labeled with Gcg-Cre lineage tracers showed a dilution of the marker at the expense of the beta-cell population throughout life [26]. Therefore, the appearance of alpha-cells at the expense of the beta-cell population may explain the long-term relapses in diabetes after SG.

Finally, the protective effect of the somatostatin-14 isoform on Min6 pancreatic beta cells of mice has recently been verified, limiting the stress markers HSPa1 and Ddit3 and apoptosis [27]. This together with the occurrence of delta-cell hyperplasia in GotoKakizaki diabetic mice [28] makes us think about a possible role of this delta population in the mechanisms underlying SG. This seems to be reinforced by the ability of ghrelin to activate the paracrine secretion of somatostatin [29] as mentioned above. However, due to the difficulty in carrying out these studies in humans and the ethical aspects, further investigation on animal models is needed to clarify this issue and the possible involvement of other pancreatic endocrine populations.

\subsection{The Roux-en-Y Gastric Bypass and the Islet Architecture}

Roux-en-Y gastric bypass appears to be the most powerful tool for the management of obesity and hyperglycemia in patients [30]. This procedure has demonstrated its efficiency in increasing beta-cell function in animal models and patients [31,32]. It also appears to increase beta-cell mass after surgery in both animal models and patients [33,34]. GLP-1 activity has been proposed as responsible for these effects on beta-cell mass after RYGB [35]. On the other hand, glucose improvement after RYGB has long been reported in mice models of functional GLP-1 and GLP-1 receptor deficiency, suggesting a GLP-1 independent mechanism for glycemic control after surgery [36]. Another very interesting candidate 
is intra-islet PYY. Guida et al. reported a large increase in islet PYY content after RYGB, mediated by locally produced PYY but not GLP-1 glucose-stimulated insulin secretion. Furthermore, interleukin-22 (IL-22) seems to play a key role in the increase of intra-islet expression of PYY after RYGB. This situation would imply that non-surgical treatment for diabetes is possible [37].

An interesting study would be to determine the participation of pancreatic delta-cells in the maintenance of beta-cell mass after RYGB surgery since a recent study demonstrated that delta-cells become insulin-expressing cells after the ablation of insulin-secreting betacells in human islets [38] (Figure 2). This should be investigated in the future.

Other cell types, such as pancreatic epsilon-cells, do not seem to be affected after RYGB [15]. However, high plasma ghrelin levels were detected in obese mice six weeks after RYGB, probably due to an expansion of ghrelin-producing cells in the duodenum and stomach of these mice [39].

On the contrary, the plasticity of the pancreatic alpha-cell population under stressful circumstances is well known. Pregnancy or intermittent fasting are capable of enhancing the alpha-cell mass in mice $[40,41]$. Some factors related to the functionality of hepatic glucagon receptors (GCgr) have been proposed as brakes and regulators of alpha-cell population expansion in animal models [42]. In this sense, RYGB is also able to cause an increase in the alpha-cell population in mice six months after the operation, including a loss of beta identity markers such as PDX-1 and a gain of alpha-cell markers such as ARX in the islets (Figure 2). All of this suggests long-term trans-differentiation of beta-cells into alpha-cells after surgery [25].

This brings us to long-term relapse of diabetes again. Like SG, the outcomes of RYGB published in relevant trials have shown a progressive worsening of diabetes-related parameters such as glycated hemoglobin, reaching a 50\% relapse in diabetes at five years [2]. Patel et al. proposed weak beta-cell function and peripheral insulin resistance as possible causes of relapse after RYGB [43]. An decrease in beta-cell mass and an increase in alphacell mass could explain this, but what is the mechanism that triggers trans-differentiation? Hyperinsulinism and subsequent hypoglycemia have been a problem after RYGB but also may be the answer [44]. In this sense, RYGB seems to cause an extreme requirement and stressful situation to the beta-cell population, triggering conversion to alpha-cells [45]. According to this, a study in patients reported hyperinsulinism but elevated postprandial glucagon secretion after RYGB. However, the same study did not report extremely increased beta cell function [46]. The landscape is complex and exciting and could be a good line of research to improve the efficiency of these surgeries in the remission of diabetes.

\section{Conclusions}

SG and RYGB are a therapeutic option not only for overweight but also for diabetes. The effects of these surgeries on enterohormonal levels have been extensively studied but on another level, further research on endocrine pancreatic cell populations is also needed. Nevertheless, it seems that different pathophysiological mechanisms underlie each of these surgeries, at least in reference to their pancreatic involvement. This is a complicated issue in humans. However, a better understanding of the mechanisms and cellular dynamics governing these populations after these two surgeries would allow us to limit hypoglycemic episodes, the relapse of diabetes over time or even the development of pharmacological alternatives to the use of bariatric/metabolic surgery.

Author Contributions: Writing—original draft preparation, J.F.-V., A.C.-R., A.D.G., J.B.d.I.R., A.R.-G., D.A.-G. and C.C.-M.; writing-review and editing, G.-M.P.-A. and J.-A.P.-O. All authors have read and agreed to the published version of the manuscript.

Funding: This research received no external funding.

Institutional Review Board Statement: Not applicable.

Informed Consent Statement: Not applicable. 
Data Availability Statement: The scientific articles consulted for the preparation of this review were obtained from the following databases: Pubmed, Science Direct, Google Academic and Rodin: (UCA Institutional Repository): It is a database of teaching and research objects of the University of Cadiz.

Conflicts of Interest: The authors declare no conflict of interest.

\section{References}

1. Mingrone, G.; Panunzi, S.; De Gaetano, A.; Guidone, C.; Iaconelli, A.; Leccesi, L.; Nanni, G.; Pomp, A.; Castagneto, M.; Ghirlanda, G.; et al. Bariatric surgery versus conventional medical therapy for type 2 diabetes. N. Engl. J. Med. 2012, 366, 1577-1585. [CrossRef] [PubMed]

2. Schauer, P.R.; Bhatt, D.L.; Kirwan, J.P.; Wolski, K.; Aminian, A.; Brethauer, S.A.; Navaneethan, S.D.; Singh, R.P.; Pothier, C.E.; Nissen, S.E.; et al. Bariatric surgery versus intensive medical therapy for diabetes 5-year outcomes. N. Engl. J. Med. 2017, 376, 641-651. [CrossRef] [PubMed]

3. Heneghan, H.M.; Nissen, S.; Schauer, P.R. Gastrointestinal Surgery for Obesity and Diabetes: Weight Loss and Control of Hyperglycemia. Curr. Atheroscler. Rep. 2012, 14, 579-587. [CrossRef] [PubMed]

4. Miras, A.D.; le Roux, C.W. Mechanisms underlying weight loss after bariatric surgery. Nat. Rev. Gastroenterol. Hepatol. 2013, 10, 575-584. [CrossRef]

5. $\quad$ Larraufie, P.; Roberts, G.P.; McGavigan, A.K.; Kay, R.G.; Li, J.; Leiter, A.; Melvin, A.; Biggs, E.K.; Ravn, P.; Davy, K.; et al. Important Role of the GLP-1 Axis for glucose homeostasis after bariatric surgery. Cell. Rep. 2019, 26, 1399-1408. [CrossRef]

6. Frezza, E.E.; Chiriva-Internati, M.; Wachtel, M.S. Analysis of the results of sleeve gastrectomy for morbid obesity and the role of ghrelin. Surg. Today 2008, 38, 481-483. [CrossRef]

7. Camacho-Ramírez, A.; Prada-Oliveira, J.A.; Ribelles-García, A.; Almorza-Gomar, D.; Pérez-Arana, G.M. The leading role of peptide tyrosine tyrosine in glycemic control after roux-en-y gastric bypass in rats. Obes. Surg. 2020, 30, 697-706. [CrossRef]

8. Honka, H.; Koffert, J.; Kauhanen, S.; Kudomi, N.; Hurme, S.; Mari, A.; Lindqvist, A.; Wierup, N.; Parkkola, R.; Groop, L.; et al. Liver blood dynamics after bariatric surgery: The effects of mixed-meal test and incretin infusions. Endocr. Connect. 2018, 7 , 888-896. [CrossRef]

9. Münzberg, H.; Laque, A.; Yu, S.; Rezai-Zadeh, K.; Berthou, H.R. Appetite and body weight regulation after bariatric surgery. Obes. Rev. 2015, 16, 77-90. [CrossRef] [PubMed]

10. Dimitriadis, G.K.; Randeva, M.S.; Miras, A.D. Potential Hormone Mechanisms of Bariatric Surgery. Curr. Obes. Rep. 2017, 6, 253-265. [CrossRef]

11. Meek, C.L.; Lewis, H.B.; Reimann, F.; Gribble, F.M.; Park, A.J. The effect of bariatric surgery on gastrointestinal and pancreatic peptide hormones. Peptides 2016, 77, 28-37. [CrossRef] [PubMed]

12. Ariyasu, H.; Takaya, K.; Tagami, T.; Ogawa, Y.; Hosoda, K.; Akamizu, T.; Suda, M.; Koh, T.; Natsui, K.; Toyooka, S. Stomach is a major source of circulating ghrelin, and feeding state determines plasma ghrelin-like immunoreactivity levels in humans. J. Clin. Endocrinol. Metab. 2001, 86, 4753-4758. [CrossRef]

13. Kalinowski, P.; Paluszkiewicz, R.; Wróblewski, T.; Remiszewski, P.; Grodzicki, M.; Bartoszewicz, Z.; Krawczyk, M. Ghrelin, leptin, and glycemic control after sleeve gastrectomy versus Roux-en-Y gastric bypass-results of a randomized clinical trial. Surg. Obes. Relat. Dis. 2017, 13, 181-188. [CrossRef]

14. Popovic, V.; Miljic, D.; Pekic, S.; Pesko, P.; Djurovic, M.; Doknic, M.; Damjanovic, S.; Micic, D.; Cvijovic, G.; Glodic, J.; et al. Low plasma ghrelin level in gastrectomized patients is accompanied by enhanced sensitivity to the ghrelin-induced growth hormone release. J. Clin. Endocrinol. Metab. 2005, 90, 2187-2191. [CrossRef] [PubMed]

15. Camacho-Ramírez, A.; Mayo-Ossorio, M.A.; Pacheco-García, J.M.; Almorza-Gomar, D.; Ribelles-García, A.; Belmonte-Núñez, A.; Prada-Oliveira, J.A.; Pérez-Arana, M. Pancreas is a preeminent source of ghrelin after sleeve gastrectomy in Wistar rats. Histol. Histopathol. 2020, 35, 801-809. [CrossRef]

16. Baena-Nieto, G.; Lomas-Romero, I.M.; Mateos, R.M.; Leal-Cosme, N.; Perez-Arana, G.; Aguilar-Diosdado, M. Ghrelin mitigates $\beta$-cell mass loss during insulitis in an animal model of autoimmune diabetes mellitus, the BioBreeding/Worcester rat. Diabetes Metab. Res. Rev. 2017, 33, e2813. [CrossRef] [PubMed]

17. Mullally, J.A.; Febres, G.J.; Bessler, M.; Korner, J. Sleeve Gastrectomy and Roux-en-Y gastric bypass achieve similar early improvements in beta-cell function in obese patients with Type 2 Diabetes. Sci. Rep. 2019, 9, 1880. [CrossRef]

18. Ugi, S.; Morino, K.; Yamaguchi, T.; Yamamoto, H.; Kaida, S.; Miyazawa, I.; Sato, D.; Sekine, O.; Fujita, Y.; Kashiwagi, A.; et al. Preserving beta-cell function is the major determinant of diabetes remission following laparoscopic sleeve gastrectomy in Japanese obese diabetic patients. Endocr. J. 2019, 66, 817-826. [CrossRef] [PubMed]

19. Garibay, D.; McGavigan, A.K.; Lee, S.A.; Ficorilli, J.V.; Cox, A.L.; Michael, M.D.; Sloop, K.W.; Cummings, B.P. Beta-cell glucagonlike peptide-1 receptor contributes to improved glucose tolerance after vertical sleeve gastrectomy. Endocrinology 2016, 157, 3405-3409. [CrossRef]

20. Garibay, D.; Lou, J.; Lee, S.A.; Zaborska, K.E.; Weissman, M.H.; Sloma, E.; Donahue, L.; Miller, A.D.; White, A.C.; Michael, A.D.; et al. $\beta$ Cell GLP-1R signaling alters $\alpha$ cell proglucagon processing after vertical sleeve gastrectomy in mice. Cell Rep. 2018, 23, 967-973. [CrossRef] [PubMed] 
21. Douros, J.D.; Lewis, A.G.; Smith, E.P.; Niu, J.; Capozzi, M.; Wittmann, A.; Campbell, J.; Tong, J.; Wagner, C.; Mahbod, P.; et al. Share enhanced glucose control following vertical sleeve gastrectomy does not require a beta-Cell Glucagon-Like Peptide 1 Receptor. Diabetes 2018, 67, 1504-1511. [CrossRef]

22. Li, F.; Cao, H.; Sheng, C.; Sun, H.; Song, K.; Qu, S. Upregulated Pdx1 and MafA contribute to $\beta$-cell function improvement by sleeve gastrectomy. Obes. Surg. 2016, 26, 904-909. [CrossRef] [PubMed]

23. Grong, E.; Kulseng, B.; Arbo, I.B.; Nord, C.; Eriksson, M.; Ahlgren, U.; Mårvik, R. Sleeve gastrectomy, but not duodenojejunostomy, preserves total beta-cell mass in Goto-Kakizaki rats evaluated by three-dimensional optical projection tomography. Surg. Endosc. 2016, 30, 532-542. [CrossRef] [PubMed]

24. Liu, T.; Zhong, M.W.; Liu, Y.; Sun, D.; Wei, M.; Huang, X.; Cheng, Y.G.; Wu, Q.Z.; Wu, D.; Zhang, X.Q.; et al. Diabetes recurrence after metabolic surgeries correlates with re-impaired insulin sensitivity rather than beta-cell function. World J. Gastroenterol. 2017, 23, 3468-3479. [CrossRef]

25. Bancalero-de los Reyes, J.; Camacho-Ramírez, A.; Fernández-Vivero, J.; Ribelles-García, A.; Macías-Rodríguez, M.; AlmorzaGomar, D.; Carrasco-Molinillo, C.; Mayo-Ossorio, M.A.; Prada-Oliveira, J.A.; Perez-Arana, G. Glucagon-producing cell expansion in Wistar rats. Changes to islet architecture after sleeve gastrectomy. Obes. Surg. 2021, 31, 2241-2249. [CrossRef]

26. Huising, M.O.; Lee, S.; Van der Meulen, T. Evidence for a neogenic niche at the periphery of pancreatic islets. Bioessays 2018, 40, e1800119. [CrossRef] [PubMed]

27. Damsteegt, E.L.; Hassan, Z.; Hewawasam, N.V.; Sarnsamak, K.; Jones, P.M.; Hauge-Evans, A. Novel Role for Somatostatin in the Survival of Mouse Pancreatic Beta Cells AC. Cell Physiol. Biochem. 2019, 52, 486-502. [CrossRef]

28. Alán, L.; Olejár, T.; Cahová, M.; Zelenka, J.; Berková, Z.; Smětáková, M.; Saudek, F.; Matěj, R.; Ježek, P. Delta Cell Hyperplasia in Adult Goto-Kakizaki (GK/MolTac) Diabetic Rats. J. Diabetes Res. 2015, 2015, 385395. [CrossRef]

29. DiGruccio, M.R.; Mawla, A.M.; Donaldson, C.J.; Noguchi, G.M.; Vaughan, J.; Cowing-Zitron, C.; van der Meulen, T.; Huising, M.O. Comprehensive alpha, beta and delta cell transcriptomes reveal that ghrelin selectively activates delta cells and promotes somatostatin release from pancreatic islets. Mol. Metab. 2016, 5, 449-458. [CrossRef]

30. Hayoz, C.; Hermann, T.; Raptis, D.A.; Brönnimann, A.; Peterli, R.; Zuber, M. Comparison of metabolic outcomes in patients undergoing laparoscopic roux-en-Y gastric bypass versus sleeve gastrectomy -a systematic review and meta-analysis of randomised controlled trials. Swiss Med. Wkly. 2018, 148, w14633. [CrossRef]

31. Inge, T.H.; Prigeon, R.L.; Elder, D.A.; Jenkins, T.M.; Cohen, R.M.; Xanthakos, S.A.; Benoit, S.C.; Dolan, L.M.; Daniels, S.R.; D'Alessio, D.A. Share insulin sensitivity and beta-cell function improve after gastric bypass in severely obese adolescents. J. Pediatr. 2015, 167, 1042-1048.e1. [CrossRef] [PubMed]

32. Lindqvist, A.; Spégel, P.; Ekelund, M.; Garcia Vaz, E.; Pierzynowski, S.; Gomez, M.F.; Mulder, H.; Hedenbro, J.; Groop, L.; Wierup, N. Gastric bypass improves $\beta$-cell function and increases $\beta$-cell mass in a porcine model. Diabetes 2014, 63, 1665-1671. [CrossRef]

33. Patti, M.E.; Goldfine, A.B.; Hu, J.; Hoem, D.; Molven, A.; Goldsmith, J.; Schwesinger, W.H.; La Rosa, S.; Folli, F.; Kulkarni, R.N. Heterogeneity of proliferative markers in pancreatic beta-cells of patients with severe hypoglycemia following Roux-en-Y gastric bypass. Acta Diabetol. 2017, 54, 737-747. [CrossRef] [PubMed]

34. Zhang, S.; Guo, W.; Wu, J.; Gong, L.; Li, Q.; Xiao, X.; Zhang, J.; Wang, Z. Increased $\beta$-cell mass in obese rats after gastric bypass: A potential mechanism for improving glycemic control. Med. Sci. Monit. 2017, 23, 2151-2158. [CrossRef] [PubMed]

35. Shah, M.; Laurenti, M.C.; Man, C.D.; Ma, J.; Cobelli, C.; Rizza, R.A.; Vella, A. Contribution of endogenous glucagon-like peptide-1 to changes in glucose metabolism and islet function in people with type 2 diabetes four weeks after Roux-en-Y gastric bypass (RYGB). Metabolism 2019, 93, 10-17. [CrossRef] [PubMed]

36. Mokadem, M.; Zechner, J.F.; Margolskee, R.F.; Drucker, D.J.; Aguirre, V. Effects of Roux-en-Y gastric bypass on energy and glucose homeostasis are preserved in two mouse models of functional glucagon-like peptide-1 deficiency. Mol. Metab. 2013, 3, 191-201. [CrossRef]

37. Guida, C.; Stephen, S.D.; Watson, M.; Dempster, N.; Larraufie, P.; Marjot, T.; Cargill, T.; Rickers, L.; Pavlides, M.; Tomlinson, J.; et al. PYY plays a key role in the resolution of diabetes following bariatric surgery in humans. EBioMedicine 2019, 40, 67-76. [CrossRef]

38. Furuyama, K.; Chera, S.; van Gurp, L.; Oropeza, D.; Ghila, L.; Damond, N.; Vethe, H.; Paulo, J.A.; Joosten, A.M.; Berney, T.; et al. Diabetes relief in mice by glucose-sensing insulin-secreting human alpha-cells. Nature 2019, 567, 43-48. [CrossRef]

39. Uchida, A.; Zechner, J.F.; Mani, B.K.; Park, W.M.; Aguirre, V.; Zigman, J.M. Altered ghrelin secretion in mice in response to diet-induced obesity and Roux-en-Y gastric bypass. Mol. Metab. 2014, 3, 717-730. [CrossRef]

40. Quesada-Candela, C.; Tudurí, E.; Marroquí, L.; Alonso-Magdalena, P.; Quesada, I.; Nadal, A. Morphological and functional adaptations of pancreatic alpha-cells during late pregnancy in the mouse. Metabolism 2020, 102, 153963. [CrossRef] [PubMed]

41. Marinho, T.S.; Borges, C.C.; Aguila, M.B.; Mandarim-de-Lacerda, C.A. Intermittent fasting benefits on alpha- and beta-cell arrangement in diet-induced obese mice pancreatic islet. J. Diabetes Complicat. 2019, 26, 107497. [CrossRef] [PubMed]

42. Longuet, C.; Robledo, A.M.; Dean, E.D.; Dai, C.; Ali, S.; McGuinness, I.; de Chavez, V.; Vuguin, P.M.; Charron, M.J.; Powers, A.C.; et al. Liver-specific disruption of the murine glucagon receptor produces alpha-cell hyperplasia: Evidence for a circulating alpha-cell growth factor. Diabetes 2013, 62, 1196-1205. [CrossRef]

43. Patel, K.; Levesque, K.; Mark, V.; Pierini, E.; Rojas, B.; Ahlers, M.; Shah, A.; Laferrère, B. Proinsulin associates with poor $\beta$-cell function, glucose-dependent insulinotropic peptide, and insulin resistance in persistent type 2 diabetes after Roux-en-Y gastric bypass in humans. J. Diabetes 2020, 12, 77-86. [CrossRef] [PubMed] 
44. Malik, S.; Mitchell, J.E.; Steffen, K.; Engel, S.; Wiisanen, R.; Garcia, L.; Malik, S.A. Recognition and management of hyperinsulinemic hypoglycemia after bariatric surgery. Obes. Res. Clin. Pract. 2016, 10, 1-14. [CrossRef]

45. Swisa, A.; Glaser, B.; Dor, Y. Metabolic stress and compromised identity of pancreatic beta cells. Front. Genet. $2017,8,21$. [CrossRef] [PubMed]

46. Georgia, A.; Asnis, M.C.C.; Febres, G.; Tsang, A.; Bessler, M.; Korner, J. Roux-en-Y Gastric Bypass is associated with hyperinsulinemia but not increased maximal $\beta$-cell. Funct. J. Endocr. Soc. 2019, 3, 632-642. [CrossRef] [PubMed] 